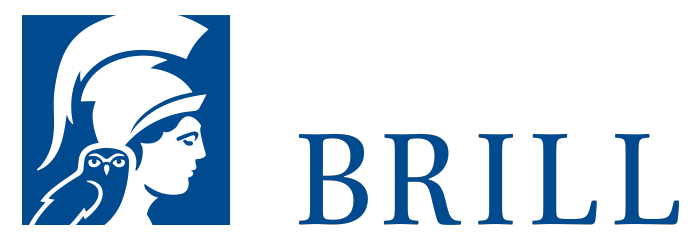

\title{
Mit Nietzsche im Stadion
}

\section{Der Fußball der Gesellschaft}

Author: Martin Gessmann

Trainer wie José Mourinho, Pep Guardiola und Jürgen Klopp stehen heute schon für eine Rede von Liberalismus, Republikanismus und einem ästhetischen Staat im Fußball. Fußball ist also keine Nebensache mehr, er ist im Herzen der Gesellschaft angekommen.

Wir schauen dem Geschehen auf dem Rasen nicht mehr nur zu, um unterhalten zu werden, sondern um darin etwas zu erfahren, was wir im Alltag nicht mehr so leicht bekommen: eine Übersicht, wie unsere Gesellschaft eigentlich funktioniert. Wie die neuzeitlichen Gesellschaften werden die modernen Mannschaften nach dem Muster rationaler Organisation ausgerichtet. Ein rein erfolgsorientiertes Spiel führt zum System eines Liberalismus, in dem die Stars konsequent auf eigene Rechnung agieren. Ein Mannschaftsgeist wird dort beschworen, wo im Namen des Fußballs eine eigene »Republik« ausgerufen wird. Und Fußball wird schließlich zu einem Spektakel, wo sich die Stilisierung der Gesellschaft am Vorbild existentieller Dramen ausrichtet.

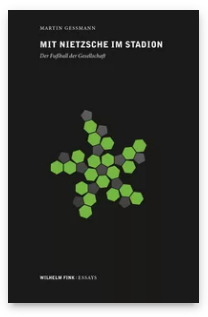

Pages: 143

Seiten

Language:

German

Subjects: 19 th \& 2oth Century

Philosophy, Philosophy

Publisher: Brill | Fink

Series:

Wilhelm Fink:

Essays

E-Book (PDF)

Released online: O5 Jun 2017

ISBN: 978-3-

8467-ooo9-9

List price

Paperback

Publication date: 22 Apr 2014

ISBN: 978-37705-5761-5

List price 
Martin Gessmann hat Philosophie, Germanstik und Romanistik in Tübingen, Nantes und Washington D.C. studiert. Nach der Disseration arbeitete er fünfJahre lang als Journalist beim öffentlich-rechtlichen Fernsehen. Die Habilitation erfolgte in Heidelberg. Seit 2012 ist er Professor für Kultur- und Techniktheorie sowie Ästhetik an der Hochschule für Gestaltung in Offenbach am Main.

For more information see brill.com

$$
\begin{aligned}
& \text { Order information: Order online at brill.com } \\
& \text { +44 } 330333 \text { o049 | customerservices@brill.com } \\
& \text { Submission information: brill.com/authors }
\end{aligned}
$$

Titles published by Brill | Fink, Brill | mentis or Brill | Schöningh: +49(o)71 5413279216 | brill@brocom.de 